\title{
An Empirical Study of International Quality Model for Education
}

\author{
Xinxing $\mathrm{Wu}$ \\ Fujian Normal University \\ Fuzhou University of International Studies and Trade \\ Fujian, China
}

\begin{abstract}
The purpose of this study is to identify the factors influencing educational quality and students' satisfaction of adult and continuing education, to examine the relationship between educational quality and students' satisfaction, and to investigate the impact of each element on students' satisfaction. The international quality model for education was used as a research instrument to measure education quality and students' satisfaction with Institutes of Continuing Education in Taiwan. Data were collected from questionnaires, and statistical analysis was carried out through factor analysis, reliability test and multiple regression analysis. Findings indicated that international quality model for education is an appropriate model for institutes of continuing education to measure educational quality and students' satisfaction. There is a significant correlation between educational quality and students' satisfaction; moreover, the elements of resource management (resources facilities, campus environment, teachers' ability), product realization (counseling and service), and measurement, analysis and improvement (learning achievement) have the ability to forecast students' satisfaction $(R 2=0.786)$, especially when the $\beta$ value of learning achievement reaches as high as 0.446.
\end{abstract}

Keywords-international quality model for education; students' satisfaction and institutes of continuing education

\section{INTRODUCTION}

International organization for Standardization (ISO) promulgated the contents and model of international quality standard in 2000, and continuously published the international education quality control guidelines for application on March in 2004 in Mexico. Therefore, how to utilize this model and its requirement into education system in our country, it is a worth topic to probe. In the past the literature seldom probed into this kind of subject, especially in adult and continuing education, so that initiates the research motivation.

There are 44 institutes of continuing education and training college in Taiwan, in which 32 institutes of continuing education subordinates the Department of Social Education of Ministry of Education, the others belong to the Department of Higher Education. The missions of institutes of continuing education are to provide the people who has job during weekday with two years program to take courses on weekend. They are awarded bachelor degree when they graduated (the Ministry of Education, 2004), this is one kind of adult and continuing education; is also one kind of recurrent education. Since it is a formal education system, its education quality should be assessed by the Ministry of Education, and the degree of satisfaction of students should also be verified, in order to conform the needs of students. The research problems are described as follows:

- Is the international quality model for education appropriate to apply for institutes of continuing education?

- Are the contents of the international quality model for education correlated with the degree of students' satisfaction of institute of continuing education?

- Could contents of the international quality model for education forecast the degree of students' satisfaction of institute of continuing education?

\section{LITERATURE REVIEW}

\section{A. International Quality Standard for Education}

To review the context of internationalization of quality control, the international standard organization (International Organization for Standardization, ISO) had established since 1947, 121 countries had participated in it around the world. ISO aims at promoting the world standardization and its interrelated matters, so as to promote the international product service exchange and cooperation. This organization promulgates the international quality control standard and integrated model in 2000 (ISO 9000: 2000), this model is suitable for all trades and professions, its main point of content is to design the customer demand into four service processes, including: the managers' responsibility, the resource management, the service realization and the measurement and analysis. The model also focuses on continuing quality improvement to meet the customers' demand, as shown in "Fig. 1 ". 


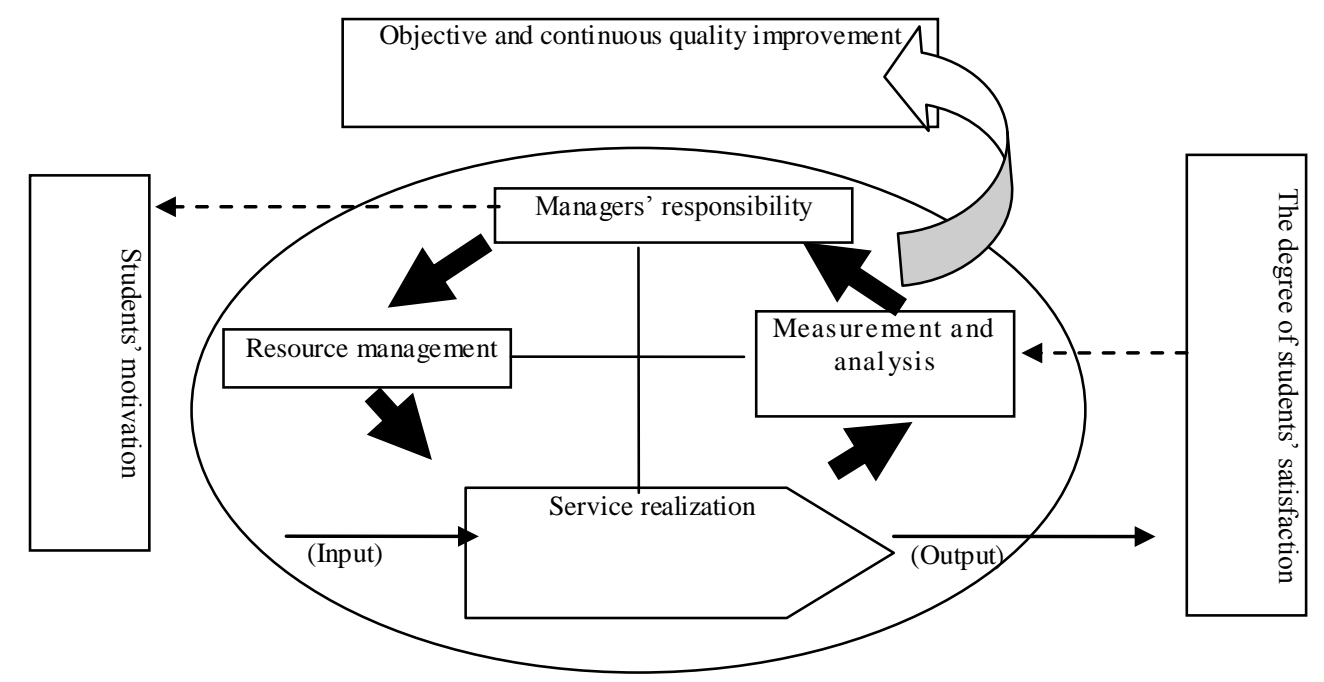

Fig. 1. International standard model (ISO 9000: 2000)

The international standard organization publishes International Workshop Agreement in March, 2004 in Mexico (to be called ISO/IWA2) for educational system to develop guidelines of quality management; the goal lies in the promotion of the education quality to conform the international quality standard for education (ISO 9000: 2000). International quality control model for education (ISO 9000/IWA2) contains five requests: education quality assurance management system, managers' responsibility, resource management, product (service) realization, measurement and analysis, and the requests are subdivided into 23 clauses, as shown in the following "Table I".

TABLE I.

CONTENTS OF THE INTERNATIONAL QUALITY MODEL FOR EDUCATION

\begin{tabular}{|c|c|c|}
\hline & Five requests & 23 articles \\
\hline 1 & $\begin{array}{l}\text { Education quality assurance } \\
\text { management system }\end{array}$ & $\begin{array}{l}\text { General requests } \\
\text { The document requests }\end{array}$ \\
\hline 2 & Managers' responsibilities & $\begin{array}{l}\text { The managers' commitments } \\
\text { The customer orientation } 3 \text {.Quality policy } \\
\text { 4.The planning } 5 . \text { The responsibility, the authority and communication 6.Management } \\
\text { review }\end{array}$ \\
\hline 3 & Resource managements & 1.Resources supply 2.Human resources 3.Infrastructure 4.The working environment \\
\hline 4 & Products realization & $\begin{array}{l}\text { 1.Product realization 2. With customer related process 3.Designs and development } \\
\text { 4.Purchases } 5 \text {. The production and the service operation } 6 \text {.Control of measurement and } \\
\text { monitoring instruments }\end{array}$ \\
\hline 5 & $\begin{array}{l}\text { Measurement analysis and } \\
\text { improvement }\end{array}$ & $\begin{array}{l}\text { 1.Outline 2. Measurement and monitoring 3. Control of nonconforming products 4.Analysis } \\
\text { of data 5.Improvement }\end{array}$ \\
\hline
\end{tabular}

The purposes of the five requirements of ISO 9000/IWA2 are not only to promote the education quality to conform the international quality standard, but also to meet the ultimate objective of the integrated model (ISO 9000: 2000)—students' satisfaction, therefore it's necessary to review the previous research of students' satisfaction.

\section{B. Factor Influencing Students' Satisfaction}

The institute of continuing education is a kind of adult and continuing education, its objective is to provide the adults on the job in the society with potential development, enrich academic principles, innovation, technological improvement and the promotion of professional qualification, to guide them to obtain new development, and to make them changing behavior. How does school enable students to satisfy their desire and attain the psychological satisfaction by teaching activities? It's necessary to measure educational quality and students' satisfaction. Li (2002) points out that "the learning satisfaction" is the learning experience of the entire learning process, according to the entire learning perception and satisfaction, this kind of feeling comes from whether the learning process could make students pleasant, and whether learning achievement could make students satisfied with the subjective feeling. Therefore, curriculum design, teaching method are the important determinants to adult education, therefore the educational organizations should not only provide students with appropriate service of education according to their characteristics, but also need to offer the high quality service which could help adults to display the nature of independent learning, and assist them to accomplish developmental tasks ( $\mathrm{Li}, 2003)$.

There are various dimensions of learning satisfaction because of the different research samples and research topics. This research reviews the literature and finds that there are nine dimensions of learning satisfaction, namely curriculum contents-1, teaching facilities-2, learning environment-3, learning achievement-4, faculties-5, interpersonal relationship- 
TABLE II.

FACTORS INFLUENCING STUDENTS’ SATISFACTION

\begin{tabular}{|c|c|c|c|c|c|c|c|c|c|}
\hline Previous Research & 1 & 2 & 3 & 4 & 5 & 6 & 7 & 8 & 9 \\
\hline ISO/IWA2,2004 & & V & $\mathrm{V}$ & $\mathrm{V}$ & $\mathrm{V}$ & & $\mathrm{V}$ & $\mathrm{V}$ & \\
\hline Shau,2004 & & $\mathrm{V}$ & & & $\mathrm{V}$ & & $\mathrm{V}$ & & \\
\hline We,2003 & & & $\mathrm{V}$ & & $\mathrm{V}$ & & $\mathrm{V}$ & & \\
\hline Shu,2001 & & $\mathrm{V}$ & $\mathrm{V}$ & $\mathrm{V}$ & $\mathrm{V}$ & $\mathrm{V}$ & & & \\
\hline Hen,2000 & & & & $\mathrm{V}$ & & $\mathrm{V}$ & $\mathrm{V}$ & & \\
\hline Lin,1998 & & & $\mathrm{V}$ & & $\mathrm{V}$ & $\mathrm{V}$ & & & \\
\hline Lee, 1998 & & & $\mathrm{~V}$ & & $\mathrm{~V}$ & & & & \\
\hline Chen,1997 & & & & $\mathrm{V}$ & & $\mathrm{V}$ & & $\mathrm{V}$ & \\
\hline Cheng,1995 & & & $\mathrm{V}$ & & $\mathrm{V}$ & $\mathrm{V}$ & & & \\
\hline Lin,1994 & $\mathrm{V}$ & $\mathrm{V}$ & & & & $\mathrm{V}$ & & & $\mathrm{V}$ \\
\hline Binner,1994 & $\mathrm{V}$ & $\mathrm{V}$ & & & $\mathrm{V}$ & & & $\mathrm{V}$ & \\
\hline $\mathrm{Wu}, 1993$ & $\mathrm{~V}$ & & & $\mathrm{~V}$ & $\mathrm{~V}$ & $\mathrm{~V}$ & & & \\
\hline
\end{tabular}

This research integrates the five main requirements of ISO/IWA2, and the literature related influential factors of students' satisfaction into five- dimension factor, namely "administration", "facilities and faculties", "teaching and student's service", "learning achievement" and "students' satisfaction". The comparisons among the international quality model for education, the previous research and this study are shown in the following "Table III".

TABLE III.

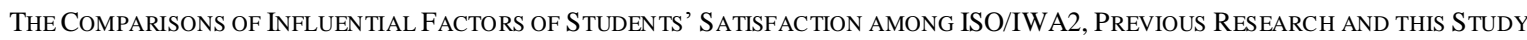

\begin{tabular}{|c|c|c|c|}
\hline & ISO/IWA2 & Previous Research & This Study \\
\hline \multirow{4}{*}{$\begin{array}{l}\text { Students' } \\
\text { satisfaction }\end{array}$} & Managers' responsibility & Administrative activities-7 & Administration \\
\hline & Resource management & Teaching facilities-2, learning environment-3, faculties-5 & Facilities and faculties \\
\hline & Product realization & $\begin{array}{l}\text { Curriculum content and design-1, counseling service-8, } \\
\text { interpersonal relationship-6, career development- } 9\end{array}$ & $\begin{array}{l}\text { Teaching and students' } \\
\text { service }\end{array}$ \\
\hline & $\begin{array}{l}\text { Measurement, analysis and } \\
\text { improvement }\end{array}$ & Learning achievement-4 & Students overall achievement \\
\hline
\end{tabular}

\section{RESEARCH Methodology}

\section{A. Research Framework}

The framework shown in "Fig. 2" has three major variables; they are independent variables (Teaching quality), dependent variables (students' satisfaction), and moderating variables (students' characteristics).

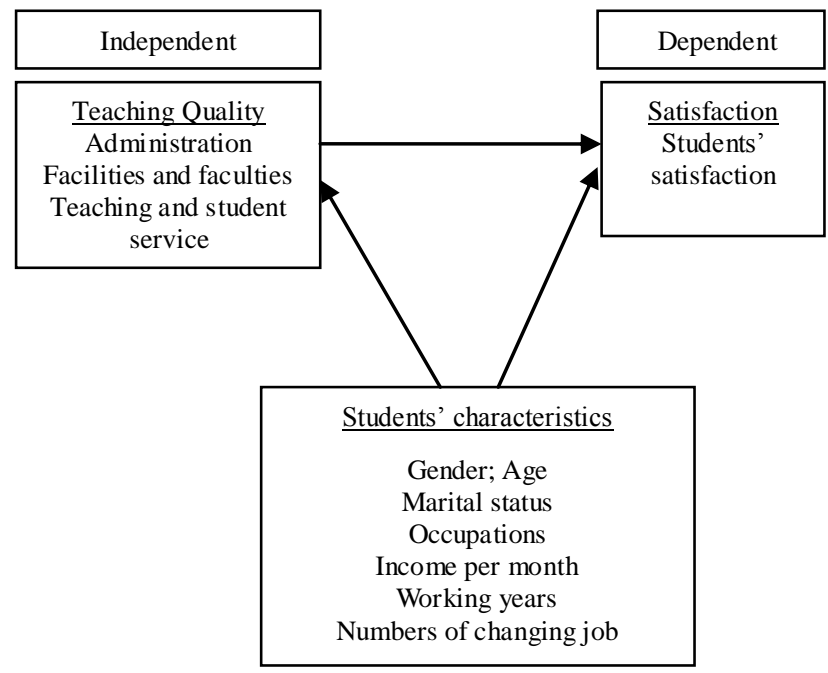

Fig. 2. Research Framework 
evaluating students' satisfaction. The responses to questions were designed according to the Likert five scales; the higher score expressed the higher performance.

The first element of part B (independent variables) is administration; the objective of the variable is to investigate the relationship between institutes' administration, such as the objective of institute's development, the administrative policy, administrative grouping and students' satisfaction. The second element is facilities and faculties, the purposes of the element is to understand the correlations between learning environment for students, various types of hardware and software facilities, the profession and enthusiastic of faculties and students' satisfaction. The third element is teaching and student services, which aim to realize the impact of the curriculum design and arrangement, the student's counseling, the interaction between institute and students and the service providing by institutes on students' satisfaction. The fourth element is students' achievement, which is used to investigate the value that students gain from the adult and continuing education, for example new knowledge, the promotion of the social position or the expansion of interpersonal relationship and so on.

The part $\mathrm{C}$ is dependent variable, namely students' satisfaction; which is the overall satisfaction of the four elements, regarding the administration, the facilities and faculties, the teaching and the student service and the student's achievement.

\section{Data Collection and Analysis Method}

There were 11 institutes of continuing education chosen through the systematic sampling to administrate the questionnaire, they are National Kaohsiung University of Applied Sciences, Tajen Institute of Technology, Tung-Fang Institute of Technology, National Chin-Yi Institute of Technology, National Formosa University, Chihlee Institute of Technology, Takming Institute, Vanung University, Jin Wen Institute of Technology, Chungchou Institute of Technology and Ming Hsin University of Science and Technology. The 1100 questionnaires were sent to the 11 institutes to ask their students to complete, then, send the completed questionnaire back to one of the researcher. 220 completed questionnaires were collected, and get a return rate of $61.5 \%$. The respondent's data of the three parts was entered into the software of SPSS $\vee$ 12.0. The reliability test, factor analysis, correlation and regression analysis were utilized to analyze the collected data.

\section{ANALYSIS RESULTS}

\section{A. Demographic Profile of Participants}

The "Table IV" will present the percentage of respondents' demographic information, in terms of gender, age, and marital status, income per month, working years and numbers of changing job.
TABLE IV.

RESPONDENTS’ DEMOGRAPHIC INFORMATION

\begin{tabular}{|c|c|c|}
\hline \multicolumn{2}{|c|}{ Demographic Information } & Percentage \\
\hline \multirow[t]{2}{*}{ Gender } & Male & $53.2 \%$ \\
\hline & Female & $46.8 \%$ \\
\hline \multirow{4}{*}{ Age } & $<20$ & $5.5 \%$ \\
\hline & $21-30$ & $54.1 \%$ \\
\hline & $31-40$ & $34.5 \%$ \\
\hline & $41-50$ & 5.9 \\
\hline \multirow[t]{3}{*}{ Marital status } & Single & $70.5 \%$ \\
\hline & Married & $26.8 \%$ \\
\hline & Divorce & $2.7 \%$ \\
\hline \multirow[t]{8}{*}{ Occupation } & Government officer & $5.0 \%$ \\
\hline & Education & $4.1 \%$ \\
\hline & Agriculture & $0.5 \%$ \\
\hline & Labor & $33.2 \%$ \\
\hline & Business & $24.1 \%$ \\
\hline & Service industry & $20.0 \%$ \\
\hline & Free industry & $3.6 \%$ \\
\hline & Others & $9.5 \%$ \\
\hline Income (per month) & $<20000$ & $13.2 \%$ \\
\hline \multirow[t]{7}{*}{$(\mathrm{NT} \$)$} & $20001-30000$ & $30.9 \%$ \\
\hline & $30001-40000$ & $33.2 \%$ \\
\hline & $40001-50000$ & $11.4 \%$ \\
\hline & $50001-60000$ & $5.5 \%$ \\
\hline & $60001-70000$ & $2.3 \%$ \\
\hline & $70001-80000$ & $0.9 \%$ \\
\hline & $>80001$ & $2.7 \%$ \\
\hline \multirow[t]{5}{*}{ Working years } & 0 & $2.7 \%$ \\
\hline & $1-5$ years & $46.4 \%$ \\
\hline & $6-10$ years & $293.5 \%$ \\
\hline & $11-15$ years & $16.4 \%$ \\
\hline & $16-20$ years & $5.0 \%$ \\
\hline \multirow{4}{*}{ Numbers of changing job } & Never & $15.0 \%$ \\
\hline & 1-2times & $39.1 \%$ \\
\hline & 3-5 times & $39.5 \%$ \\
\hline & $>$ 6times & $6.4 \%$ \\
\hline
\end{tabular}

B. Factor Analysis and Reliability Analysis

Factor analysis is a multivariate statistical technique, which would confirm the dimensions of the concept that have been operationally defined, as well as indicate which of the items are most appropriate for each dimension. The principal component factor analysis was used to extract the factors, which Eigen value is bigger than 1, finally the varimax variation was utilized to make the factor rotation, and the questions of low loading (less than 0.45) were cut off (Samon, 1999).

The reliability of the four elements of teaching quality and students' satisfaction were examined using reliability test program of SPSS version 12.0. All the values are more than .70, and met the recommended standard Alpha > .70 (Hair 
et al. 1998). The results of factor analysis and reliability test are shown in "Table V".

TABLE V. RESUlt OF FACTOR ANALYSIS AND RELIABILITY TEST

\begin{tabular}{|c|c|c|c|c|}
\hline Variables & Questions & KMO & $\begin{array}{c}\text { The } \\
\text { Accumulation \% } \\
\text { to Explain the } \\
\text { Variation }\end{array}$ & Alpha \\
\hline \multirow[t]{8}{*}{$\begin{array}{l}\text { Independent } \\
\text { variables }\end{array}$} & $\begin{array}{l}\text { Resources } \\
\text { facilities }\end{array}$ & \multirow{2}{*}{0.874} & \multirow{2}{*}{$55.379 \%$} & $\overline{0.8500}$ \\
\hline & $\begin{array}{l}\text { Administrative } \\
\text { policy }\end{array}$ & & & 0.8365 \\
\hline & $\begin{array}{l}\text { Teachers' } \\
\text { ability }\end{array}$ & \multirow{3}{*}{0.899} & \multirow{3}{*}{$65.616 \%$} & 0.8784 \\
\hline & $\begin{array}{l}\text { Curriculum and } \\
\text { teaching }\end{array}$ & & & 0.8693 \\
\hline & $\begin{array}{l}\text { Campus } \\
\text { environment }\end{array}$ & & & 0.8243 \\
\hline & $\begin{array}{l}\text { Counseling } \\
\text { service }\end{array}$ & \multirow[t]{2}{*}{0.929} & \multirow[t]{2}{*}{$63.572 \%$} & $\overline{0.9348}$ \\
\hline & Tuition fee & & & 0.7793 \\
\hline & $\begin{array}{l}\text { Learning } \\
\text { achievement }\end{array}$ & 0.924 & $63.995 \%$ & 0.9290 \\
\hline $\begin{array}{l}\text { Dependent } \\
\text { variables }\end{array}$ & $\begin{array}{l}\text { Learning } \\
\text { satisfaction }\end{array}$ & 0.690 & $55.622 \%$ & 0.7322 \\
\hline
\end{tabular}

\section{Hypotheses Testing and Regression Analysis}

This research proposed eight hypotheses based on the study construction and the result of the factor analysis, and the stepwise regression analysis was proceeded to test the following eight hypotheses.

H1 : The administrative policy has significant impact on learning satisfaction.

H 2 : Resources facilities have significant impact on learning satisfaction.

H 3 : Campus environment has significant impact on learning satisfaction.

H 4 : Teacher ability has significant impact on learning satisfaction.

$\mathrm{H} 5$ : The curriculum and teaching has significant impact on learning satisfaction.

H 6 : Counseling service has significant impact on learning satisfaction.

H 7 : The charge prizes have significant impact on learning satisfaction.

H 8 : Learning achievement has significant impact on learning satisfaction.

Firstly, the Pearson correlation analysis was used to investigate the correlation of eight influential factors and students' satisfaction; the result discovered eight factors have significant correlations with students' satisfaction, as shown in "TableVI".

TABLE VI.

THE PEARSOn CORRELATION ANALYSIS

\begin{tabular}{|l|l|l|l|l|l|l|l|l|l|}
\hline \multicolumn{1}{|c|}{ Factors } & F1 & F2 & F3 & F4 & F5 & F6 & F7 & F8 & F9 \\
\hline F1:Resources facility & 1.00 & & & & & & & & \\
\hline F2:Administrative policy & .581 & 1.00 & & & & & & & \\
\hline F3:Leachers' ability & .331 & .318 & 1.00 & & & & & & \\
\hline F4: Curriculum and teaching & .377 & .464 & .677 & 1.00 & & & & & \\
\hline F5:Campus environment & .566 & .479 & .387 & .530 & 1.00 & & & & \\
\hline F6: Counseling service & .603 & .637 & .497 & .549 & .547 & 1.00 & & & \\
\hline F7: Tuition fee & .457 & .385 & .436 & .446 & .424 & .693 & 1.00 & & \\
\hline F8: Learning achievement & .383 & .484 & .644 & .690 & .494 & .615 & .512 & 1.00 & \\
\hline F9: Students' satisfaction & .597 & .603 & .645 & .658 & .615 & .737 & .615 & .800 & 1.00 \\
\hline
\end{tabular}

The following section initially used stepwise multiple regressions to reveal the predictors of students' satisfaction. In stepwise regression, the variable with the strongest correlation that can meet the entry criteria was entered first, so model 1 contained first one predictor- learning achievement, following resources facilities, counseling service, teachers ability, campus environment were entered. The five variables, explained $79 \%$ variation of students' satisfaction. The regression results were shown in "Table VII" and "Table VIII". 
TABLE VII. VARIATION ANALYSIS OF REGRESSION ANALYSIS

\begin{tabular}{|c|c|c|c|c|c|}
\hline & Sum of Square & $\begin{array}{c}\text { Degree of } \\
\text { Freedom }\end{array}$ & $\begin{array}{c}\text { Average Sum of } \\
\text { Square }\end{array}$ & F Test & Significance \\
\hline Amount & 71.857 & 219 & & 161.621 & .000 \\
\hline
\end{tabular}

TABLE VIII. RESULTS OF THE REGRESSION ANALYSIS

\begin{tabular}{|c|c|c|c|c|c|}
\hline & \multicolumn{2}{|c|}{ Non-Standardized } & \multirow{2}{*}{$\begin{array}{c}\text { Standardized } \\
\text { Beta }\end{array}$} & \multirow{2}{*}{$\begin{array}{c}\mathbf{T} \\
\text { Values }\end{array}$} & \multirow{2}{*}{ Significant } \\
\hline & Beta & Standard error & & & \\
\hline Constant & $4.820 \mathrm{E}-02$ & .124 & & .390 & .697 \\
\hline Learning achievement & .407 & .043 & .446 & 9.578 & .000 \\
\hline Resources facilities & .167 & .039 & .180 & 4.279 & .000 \\
\hline Counseling service & .187 & .040 & .218 & 4.663 & .000 \\
\hline Teachers ability & .135 & .039 & .144 & 3.459 & .000 \\
\hline Campus environment & $9.55 \mathrm{E}-02$ & .033 & .118 & 2.862 & .005 \\
\hline
\end{tabular}

\section{DISCUSSION}

Some implications emerged from regression analysis were mentioned above and will be discussed as follows:

There are five variables among the eight independent variables have significant impact on students' satisfaction, they are resources facilities, campus environment, teachers ability, counseling service and learning achievement. However, the other three variables have no significant impact on students' satisfaction, in terms of curriculum and teaching, administrative policy and tuition fee.

The five variables could explain 79 percent $(\mathrm{R}=0.889$, $\mathrm{R} 2=0.791$ ) of the variation of students' satisfaction, so it can be said that it is a good model to explain students' satisfaction. The five variables mentioned above have significant influences on students' satisfaction $(\mathrm{F}=161.621, \mathrm{P}<0.000)$, and the $\beta$ value of "learning achievement" is the biggest $(\beta=0.446)$.

The regression equation could be expressed as follows:

Students satisfaction $=0.048+0.407 *$ learning achievement $+0.167 *$ resources facilities $+0.187 *$ counseling service $+0.135 *$ faculties ability $+0.096 *$ campus environment.

In sum, this study supports $\mathrm{H} \mathrm{2,} \mathrm{H} \mathrm{3,} \mathrm{H4,} \mathrm{H} 6$ and $\mathrm{H} 8$ and rejects $\mathrm{H} 1, \mathrm{H} 5$ and $\mathrm{H} 7$, as shown in the following "Table IX”.
TABLE IX.

THE RESUlTS OF HyPOTHESES TESTING

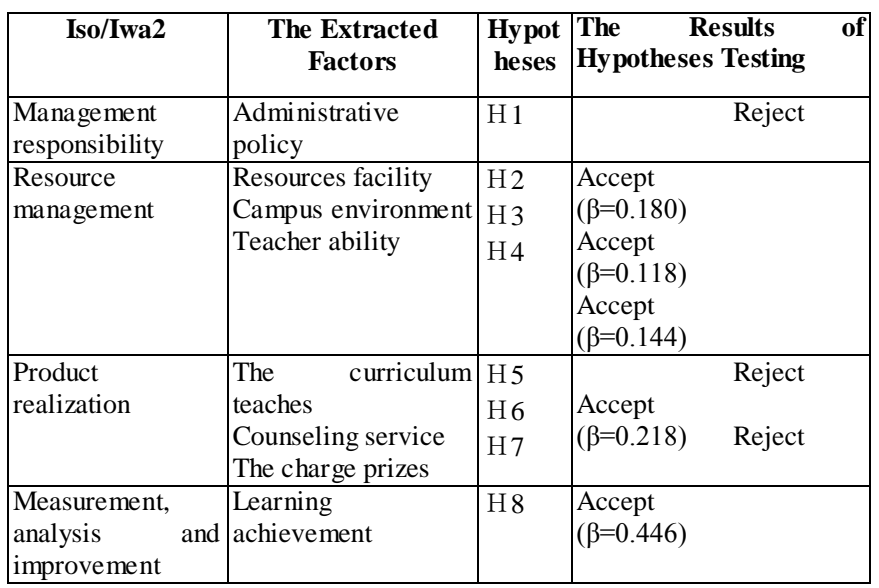

According to the results and the research questions will be answered as follows:

- The international quality model for education is appropriate to apply for institutes of continuing education.

- The contents of the international quality model for education are strong correlated with the degree of students' satisfaction of institute of continuing education.

- The contents of the international quality model for education could forecast the degree of students' satisfaction of institute of continuing education.

\section{CONCLUSION}

The study utilized the integrated model of international quality for education to identify the factors influencing educational quality and students' satisfaction of adult and continuing education. The findings of the study are that eight 
elements of teaching quality have correlation with students' satisfaction. Among the eight elements, there are five elements, namely learning achievement, resources facilities, counseling service, teacher's ability and campus environment, are able to forecast students satisfaction, and the learning achievement has the strongest impact on students satisfaction. However, the administrative policy, teaching curriculum and tuition fee have no significant impact on students' satisfaction. The probable reasons are that the students of adult and continuing educations are almost getting job, so they support the tuition fee for themselves, and have no financial difficulty. What they concern is whether they could obtain knowledge and technique to improve their salary and life quality.

This research makes a contribution to both practice and academic knowledge of adult and continuing education. It bridges the research gap in the relationship between education quality and students' satisfaction and also offers a solid foundation for future academic research. The contribution in academic is, to the author's knowledge, the first piece of research to study the relationship between teaching quality and students' satisfaction in Taiwan using the ISO/IWA2 model in Institutes of Continuing Education. The ISO/IWA2 model could be seen as an appropriate model to measure teaching quality and students' satisfaction. In practice, the instrument developed in this study can be useful for a snapshot view of what may be facilitating or inhibiting features of students' satisfaction. The successful practice of ISO/IWA2 depends on continuous self-assessment to identify the opportunities for improvement. Therefore, Institutes of Continuing Education that are providing a quality teaching service should consider ISO/IWA2 as a strategy that will help them to become more successful Institutes of quality in education.

This study suggests that the efforts in learning achievement, resources facilities, counseling service, faculty ability and campus environment are more likely to be fruitful than efforts in improving administrative policy, teaching curriculum and tuition fee. Moreover, ISO/IWA2 is a comprehensive management approach, and the elements of ISO/IWA2 are inter-dependent and influence one another. In search of high teaching quality and students' satisfaction, it has been suggested that a systematic perspective is necessary.

\section{REFERENCES}

[1] Brennan, J and Shah, T. (2000). Managing Quality in Higher Education; an International Perspective on Institutional Assessment and Change. OECD, the Society for Research into Higher Education \& Open University.

[2] Cavana, R. Y., Delahaye, B. L. \& Sekaran, U. (2001). Applied business research: Qualitative and quantitative methods. Australia: John Wiley \& Sons Australia, Ltd.

[3] Green, D (1994). What is Quality in Higher Education? Society for Research into Higher Education \& Open University.

[4] Higher Education Division. (2001). Quality of Australian Higher Education; International Quality Assurance and Improvement plans for the 2001-2003 Triennium. Commonwealth of Australia: Department of Education Training Youth Affairs.

[5] Higher Education Funding Council for England (2001). A Guide to the 2001 Research Assessment Exercise.

[6] ISO 9000 (2000). Retrieved from http://www.iso.org.
[7] ISO $9000 /$ IWA2 (2004). Retrieved from http://www.iso.org

[8] Mckinon, K. R., Walker, S. H., and Davis, D. (2000) Benchmarking; A Manual for Australian Universities. Commonwealth of Australia: Department of Education, Training and Youth Affairs.

[9] Nichols, J (1995). Assessment case studies: common issues in implementation with various campus approaches to resolution. New York: Agathon Press.

[10] International Workshop Agreement 2 (2004). Quality management systems-guideline for the application of ISO 9001: 2000 in education.

[11] Sekaran, U. (1992). Research methods for business: A skill building approaches (2nd Ed.). New York: John Wiley \& Sons

[12] U.S. News and World Report (2000, December). 2001 College. 